\title{
Students' and Teachers' Perceptions About Hospital Educational Environment In Selected Postgraduate Medical Institutes of Bangladesh
}

\author{
Dr. Dilara Alo ${ }^{1}$, Prof. Dr. Md. Humayun Kabir Talukder ${ }^{2}$, Dr. Riffat Rahim ${ }^{3}$
}

\begin{abstract}
This descriptive type of cross sectional study was carried out to observe the hospital educational environment of selected postgraduate medical institutes of Bangladesh. Study period was from July 2016 to June 2017.Sample size was 289 postgraduate clinical students of various course (MD, FCPS \& Diploma) and 20 clinical teachers of 10 selected postgraduate medical institutes of Bangladesh. Convenience sampling technique was adopted. Data collection was done with self- administered semi-structured questionnaire using Postgraduate Hospital Educational Environment Measurement (PHEEM) inventory and by In-depth interview of teachers. Three subscales of PHEEM are students' perceptions about 'role autonomy', students' perceptions about quality of teaching and students' perceptions about social support. In-depth interview of the clinical teachers was undertaken to explore the training facilities in the selected postgraduate medical institutes of Bangladesh. Study result revealed total PHEEM score was110.08. Mean score of subscales of PHEEM were $34.51,36.29$ and 26.28 for 'role autonomy', quality of teaching and social support respectively. All these values indicates that the students' perception were in the right or positive direction. Analysis of individual items had shown mean score of most of the individual item were 2-3 that indicated the aspects of the climate that could be enhanced. There were few items that had mean score 2 or less than 2 that indicated the problematic areas of hospital educational environment. In-depth interview of the teachers revealed that there was also some problematic issues on postgraduate training facilities like work overload, lack of proper monitoring or supervision of training, inadequate library, internet, ICU and investigation facilities etc. Study recommended that significant attention should be paid in the problematic areas (lack of supervised training, heavy work load of student, lack of library facility etc.) as well as improvement needed on several areas of hospital educational environment of postgraduate medical institutes of Bangladesh.
\end{abstract}

Key Words: Students' and teachers' perceptions, hospital educational environment, Postgraduate Medical Institutes of Bangladesh.

\section{Introduction}

The educational environment is a dynamic, complex structure with multiple inter-related and interactive facets that involve the trainee, the trainee's interactions with his peers, supervisors, and other members of the team, the training program and the structure of the organization that one works in ${ }^{1}$. The American Medical Association defines it as "a social system that includes the learner, the individuals with whom the learner interacts, the setting(s) and purpose(s) of the interaction, and the formal and informal rules/policies/norms governing the interaction." The educational environment is an important educational measure in the quality of the medical undergraduate and post-graduate training. Now a days, the students' and teachers' perceptions are of fundamental importance that provides valuable feedback of the efficiency and

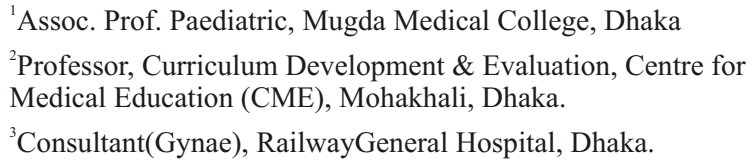

Address of correspondence: Dr. Dilara Alo

Assoc. Prof. Paediatric, Mugda Medical College, Dhaka

Emal: dilaraalo15@gmail.com acceptability of educational method and learning experience 2. The Accreditation Council for Graduate Medical Education (ACGME) has recently introduced the Clinical Learning Environment Review (CLER) which was designed to optimize the clinical learning environment "to achieve safe and high quality of patient care". ${ }^{3}$

\begin{abstract}
Methodology:
This descriptive type of cross sectional study was conducted among 289 postgraduate students of different courses and 20 clinical teachers in the Medicine faculty of conveniently selected 10 postgraduate medical institutes of Bangladesh. Study period was from July 2016 to June 2017. Data were collected by self -administered semi-structured questionnaire using Postgraduate Hospital Educational Environment Measurement (PHEEM) inventory described by Roff, 2005 from the students and In-depth interview schedule from concerned teachers. In-depth interview schedule of concerned teachers was done to obtain perceptions on post-graduate training facilities. Pretesting was done on 20 students and 2 teachers of postgraduate medical institutes to revise the questionnaire. The dean of Medicine Faculty of BSMMU and academic directors or principals of postgraduate medical institutes were duly informed and permission was taken. A scheduled time was
\end{abstract}

Bangladesh Journal of Medical Education 2018;9(1):7-9. C 2018 Alo et al., publisher and licensee Association for Medical Education. This is an Open Access article which permits unrestricted non-commercial use, provided the original work is properly cited. 
selected for data collection on the different occasion. In depth interview was undertaken after taking schedule time and consent from 20 concerned teachers. Note taking during in-depth interview was done with concurrent tap recording where possible. The entire questionnaire was checked and edited to reduce errors. Then data were entered into computer and analysis was performed by using SPSS program.

\section{Results}

Table 1: Distribution of respondents by mean score on students' perception on sub scales of PHEEM

\begin{tabular}{lccc}
\hline $\begin{array}{l}\text { Students' perception on Sub scales of } \\
\text { PHEEM }\end{array}$ & $\begin{array}{c}\text { Maximum score of subscale of } \\
\text { PHEEM }\end{array}$ & $\begin{array}{c}\text { Mean score on students' } \\
\text { perceptions }\end{array}$ & $\begin{array}{c}\text { Interpretation on } \\
\text { students' perceptions }\end{array}$ \\
\hline Role Autonomy & 56 & 34.53 & More positive perception \\
Quality of teaching & 60 & 36.29 & Moving in right direction \\
Social support & 44 & 26.28 & More pros than cons \\
Total PHEEM score & 160 & 110.08 & $\begin{array}{c}\text { More positive than } \\
\text { negative but room for } \\
\end{array}$ \\
& & & improvement \\
\hline
\end{tabular}

Table-1shows distribution of mean score on students' perception on sub scales of PHEEM. There was highest mean score (36.29) in the subscale of quality of teaching and lowest mean score in the subscale of social support (26.28).

Table 2: Distribution of statements of PHEEM by item mean score 2 or less than 2

\begin{tabular}{ll}
\hline Statements of PHEEM & Mean \pm SD \\
\hline Availability of textbooks in the department & $1.76 \pm 1.090$ \\
workload in this job is optimum & $1.74 \pm 1.101$ \\
Having adequate time for personal learning & $1.81 \pm 1.082$ \\
Having good clinical supervision at all time & $1.88 \pm 1.055$ \\
Having good quality accommodation for junior & $1.74 \pm 1.116$ \\
doctors when in call & \\
All clinical teachers have good supervision skills & $1.80 \pm 1.056$ \\
All clinical teachers are well organized & $1.94 \pm 1.051$ \\
\hline
\end{tabular}

Table- 2 shows distribution of statements by item mean score 2 or less than 2.Mean score of all these statements indicated problem points.

\section{Discussion}

The overall PHEEM score indicated the postgraduate students' perceptions on hospital educational environment were positive. Total PHEEM score of this study is consistent with the study done by Aspegren et $\mathrm{al}^{4}$ and Lucas \& Samarage. ${ }^{5}$ But Clapham et al..$^{6}$ showed the total PHEEM score was lower. Higher score was found in Nizeria and Nepal in the study of Roff et.al ${ }^{7}$. The mean scores of all three subscales of PHEEM inventory show positive perceptions. This finding is consistent to some extent with the study of Gough \& Bullen ${ }^{8}$ done in the Victoria hospital of Melbourn and also in the study of Vieira ${ }^{9}$ and Shokoohi et al. ${ }^{10}$ Aspegren et al ${ }^{4}$ had lower score shown in the subscale of role autonomy and social support of PHEEM inventory in the study done in the Danish hospital setting. Most of items (29 items) of all 3 subscales have mean score between 2 and 3 are aspects of the climate that could be enhanced. Several items had mean score of 2 or less, indicated problem areas. Problematic areas were also observed in the other studies ${ }^{4,8}$ $9,10,11,12$. The problematic areas revealed in this study were increased work load, less time for self- learning, lack of supervision etc. Analysis of comments on the statements mentioned in the self- administered semi-structured questionnaire revealed that there is adequate number of varieties of patients but work load is very high. There is lack of library, internet, ICU and investigation facilities needed for postgraduate clinical education. Again political or local influences and lack of devoted, knowledgeable teachers are the emerging threats for post graduate clinical education. Indepth interviews of teachers of in selected postgraduate institutes revealed that postgraduate teachers need orientation to develop skill for monitoring of training, teaching and assessment or evaluation of postgraduate students. They also mentioned that regular supervision of hospital educational environment of postgraduate students by BCPS or BSMMU is needed for accreditation of the post graduate institutes.

\section{Conclusion}

In this study students' perceptions on hospital postgraduate educational environment were positive. Students' perceptions and In-depth interview of teachers revealed some problematic issues. Supervised postgraduate training with library, ICU, internet, investigation and accommodation facilities, hospital workload of students, teachers' skill regarding teaching, supervision and assessment, have come out to be the main intervention areas for further development of the hospital educational environment of postgraduate medical institutes of Bangladesh.

\section{References}

1. Harden RM.The learning environment and curriculum. Medical Teacher 200;23:335-336. 
3. BM\&DC (Bangladesh Medical and Dental Council) 2002,Curriculum for Undergraduate Medical Education in Bangladesh 2002.DGHS, Dhaka.

4. Swanwick, T 2010. Understanding Medical Education: Evidence, Theory and Practice. London Deanery: Wiley Blackwell Publication. 195-270.

5. Tarrant, M \& Ware J 2008.'Impact of item-writing flaws in multiple-choice questions on student achievement in high-stakes nursing assessments'. Medical Education, $42(2), 198-206$.

6. Schuwirth, LWT \& van der Vleuten, CPM 2013. 'Written assessment' in JA Dent \& RM Harden (eds). A Practical for Medical Teachers. Churchill Livingstone, Elsevier Limited 299-306.

7. Rules \& Procedure 2006. 'Rules\& Procedures for the conduction of $2^{\text {nd }}$ Professional MBBS Examination in Pharmacology under new curriculum'. University of Dhaka.
8. Sindhu, S, Singh, HK, Saiman, MT \& Verma, VK 2011. 'Comparative Evaluation of Pharmacology Question Papers in Medical Colleges Affiliated to Different Universities in North India along with Recommendation'. Journal of research in Medical Education \& Ethics, 1(3),180 -186.

9. Karim, A \& Haque, M 1996. 'Assessment system in Pharmacology- Does it Reflect Educational objectives and Community Health Needs'? Bangladesh J Physiol Pharmacol,12(2): 65-67.

10. Begum,M, Rahman, MS, Islam, AFMS, Khan, IA \& Akhter, N 1999. 'Eleven Years of the Undergraduate Medical Curriculum 1988: review on the changes in Pharmacology written questions'. Bangladeh $j$ PhysiolPharmacol, 15(1), 27-30.

11. Manara, A, Uddin, MN, Habib MA \& Ayub, M 2012. 'Reflection of SAQ in Undergraduate Anatomy MBBS Course according to New Curriculum of BMDC'. JAFMC Bangladesh, 8(2): 3-7. 